\title{
Can States be Corporately Liable to Attack in War?
}

François Tanguay-Renaud

Osgoode Hall Law School of York University, ftanguay-renaud@osgoode.yorku.ca

Source Publication:

The Ethics of War (Oxford University Press)

Follow this and additional works at: https://digitalcommons.osgoode.yorku.ca/scholarly_works

Part of the Military, War, and Peace Commons

\section{Repository Citation}

Tanguay-Renaud, François, "Can States be Corporately Liable to Attack in War?" (2017). Articles \& Book Chapters. 2610.

https://digitalcommons.osgoode.yorku.ca/scholarly_works/2610

This Book Chapter is brought to you for free and open access by the Faculty Scholarship at Osgoode Digital Commons. It has been accepted for inclusion in Articles \& Book Chapters by an authorized administrator of Osgoode Digital Commons. 


\section{CAN STATES BE CORPORATELY LIABLE TO ATTACK IN WAR?}

François Tanguay-Renaud

\section{Introduction: States as Collectives and Liability-One Underexplored Starting Point}

Under the influence of Jeff McMahan's groundbreaking work, many recent writings in Just War theory have taken a fundamentally individualistic turn in their approach to the morality of war. ${ }^{1}$ It is individuals' actions that make wars unjust, and it is individuals' liability and moral value that govern how wars should be fought. Collectives' existence, rights, or liability have no salient moral role to play, and insofar as they figure in discussions of the morality of war, it is merely as shorthand for deeper individualistic complexities. Such radical reductive individualism is generally asserted in reaction to a longstanding theoretical tradition according to which the morality of war applies primarily to the acts of collective entities-namely, states-and only derivatively to the acts of individuals, such that otherwise familiar principles of individual morality do not apply in that context. ${ }^{2}$ To be sure, one of the most strident rallying cries of individualist theorists is that traditional war doctrines that ascribe irreducible moral salience to

* I wish to thank Vincent Chiao, Helen Frowe, Adil Haque, Seth Lazar, Victor Tadros, Helga Varden, and Ekow Yankah for their comments in the context of two workshops where this essay was presented. I also thank the editors of this volume for their written comments. This research was made possible by a grant from the Social Sciences and Humanities Research Council of Canada.

1. See Jeff McMahan, Killing in War (Oxford: Oxford University Press, 2009), as well as, for example, Helen Frowe, Defensive Killing (Oxford: Oxford University Press, 2014).

2. The loci classici of this tradition include Jean-Jacques Rousseau, The Social Contract, ed. and trans. Gerald Hopkins, in The Social Contract and Other Political Writings (Cambridge: Cambridge University Press, 1997), I.4.9; Michael Walzer, Just and Unjust Wars (New York: Basic Books, 1977). 
states almost invariably end up overlooking crucial differences in the moral position of individual participants in wars-including differences that stem from the justice or injustice of their respective causes and, among unjust participants, from the kind and degree of their involvement in warfare.

The appeal of this line of criticism lies primarily in its promise of greater moral discernment. Accordingly, theorists who champion it ought to be especially wary of overgeneralizations and non sequiturs. Indeed, even if traditionalist doctrines such as the moral equality of combatants and civilians' absolute immunity are flawed and ordinary individual distinctions are as central to the morality of war as they are to morality more generally, it does not necessarily follow that states are a mere shorthand in evaluations of how wars should be fought. If one is prepared to hold, as many do, that at least some organized collectives, such as some commercial corporations and non-governmental organizations, can make additional moral differences in the world - that is, moral differences that are not fully reducible to those of their individual members-why would it not also be the case for states? McMahan himself recognizes that "there is no reason to suppose that states, or any other kinds of political collectives, are fundamentally different morally from collectives that are not political in nature," and that "the principles governing collective violence in war should be the same as those governing collective action in domestic contexts." 3 If that is true and, in war or otherwise, states, like corporations and NGOs, can, for example, engage in distinctively collective wrongdoing or otherwise make themselves liable to adverse actions qua collectives, then a full account of the morality of war may be well advised to take such facts into account. That is, war theorists may have to account for this collective reality alongside all the complex and important individual moral distinctions at play. Unlike what much of traditional Just War theory and contemporary individualist retorts would have us believe, the resulting moral picture may then be more, not less, complex.

My goal in this essay is to begin to investigate one salient moral difference that states qua group agents may intuitively be thought to make in war, assuming that such agents exist. My focus will be on the idea of liability to attack, central to much recent individualist Just War theorizing. Those liable to attack, McMahan contends, "would not be wronged by being attacked, and would have no justified complaints about being attacked." ${ }^{\prime}$ This leads me to ask: insofar as states are corporate group agents, might they ever intelligibly be said to be liable in this sense qua groups? If so, could such corporate liability ever make a difference in an over-

3. McMahan, Killing in War, 156.

4. Ibid., 8 . 
all argument about the permissibility of attacking a state? In this essay, I argue that, if some states are indeed responsible corporate agents, the possibility of their liability to attack is at least intelligible and, in some cases, may be morally determinative. However, I also contend that, insofar as one is committed to the principle of value individualism (and perhaps even otherwise), cases in which state corporate liability is morally salient are likely to be rare and restricted to very specific sets of circumstances.

I take as my point of departure Christian List and Philip Pettit's account of group agency, ${ }^{5}$ which, in my view, is currently the most developed and intuitively plausible available. The account holds, first, that groups such as states can be conversable agents in their own right, in the manner of individual human beings. That is, they can be constituted in ways that make it possible to reason and do business with them over time qua groups - for example, by entering into treaties or contracts with them, reasonably expecting that these will be honored. For such conversability to be possible, the group needs, of course, to be responsive to the attitudes and inputs of its individual members. However, it must also be responsive in a way that secures group sensitivity to reason over time, with a minimum of consistency and coherence. According to List and Pettit, these features can obtain when the group functions in keeping with an adequate normative framework, or constitution. A constitution is adequate in this sense when it sets out a decision procedure that ensures that the organized group's judgments, as well as action-directing attitudes and plans are, on the whole, functionally independent, as opposed to a mere reflection, of the corresponding judgments, attitudes, and plans of group members. Thus, autocratic decision procedures, according to which decisions are merely those of an individual dictator and no real group decisions are taken, are clearly inadequate. In such cases, there is no conversable group agent-only the dictator himself.

What a constitution must ensure is the group's relative autonomy, in the sense of enabling it to form judgments, attitudes, and plans that cannot fully be reduced to those of one or more group members. One might think of some forms of majoritarian democracy in such terms. For the sake of simplicity, consider the following three-person example, where $\mathrm{A}, \mathrm{B}$, and $\mathrm{C}$ are deciding whether $\mathrm{X} \&(\mathrm{Y} \& \mathrm{Z})$. If A believes $X \&(Y \& \neg Z)$, B believes $X \&(\neg Y \& Z)$, and $C$ believes $\neg X \&(Y \& Z)$, then if the group votes on each of $X, Y$, and $Z$ in turn, the group will hold that $\mathrm{X} \&(\mathrm{Y} \& \mathrm{Z})$ although none of the members believes this.

5. Christian List and Philip Pettit, Group Agency: The Possibility, Design, and Status of Corporate Agents (Oxford: Oxford University Press, 2011). 
An additional issue arises here, as it does with other decision-making procedures for aggregating individual judgments into group judgments. ${ }^{6}$ Broadly stated, individual responsiveness - in my example, to the beliefs of A, B, and Cmay, over time, compromise the minimal rational consistency that we expect from agents proper. So, for conversable group agency to be possible, a process must also be in place to ensure that the group keeps track of where its accumulating decisions are taking it, and can respond appropriately to that information. In other words, balances and checks must be in place to make sure that, over time, the group can revise its corporate judgments so as to restore reasonable consistency.

One of the great strengths of this kind of account is that it rests on the nonmysterious premise that group agents derive all their matter and energy from their individual members. It is through their individual members that organized groups can access evidence and gain the understanding required to make evaluative judgments about the reasons for action and normative options they face. The overall contention, though, is that, by jointly committing and adhering to an adequate constitution, group members can generate a single, relatively autonomous, and enduring corporate agent that, when faced with normatively significant choices, is capable of making irreducible and reasonably consistent judgments about how it should respond-about what is good and bad, right and wrong. This corporate agent, which in an important sense has a mind of its own, may then formulate objectives, make decisions, and develop strategies and plans to implement these over time, all in a saliently irreducible way. It may also control for the execution of such plans by arranging things so that some individuals are directed, or empowered, to perform relevant tasks, while others are identified as possible back-ups. As List and Pettit argue, a corporate agent that arranges for action in this way is fit to be held responsible, and may appropriately be blamed, as "the source of the deed" or the "planner" at its origin.7 Of course, the individuals who give life to such an agent still have to answer for what they do in making corporate agency possible. They remain moral agents in their own right. However, the entity they maintain also has to answer as a whole for what it does at the corporate level.

As complex organizations that deal diachronically with their members as well as with other organizations and individuals, endure alterations in membership,

6. In Group Agency, chaps. 2-3, List and Pettit consider various other premise aggregation procedures, sequential priority decision procedures, as well as more complex distributed premisebased procedures among subgroups.

7. List and Pettit, Group Agency, chap. 7. For a discussion, expanding beyond List and Pettit's work, of the various kinds of multilevel causal control and structural control that make group responsibility salient, over and above the responsibility of individual enactors, see Anders Strand, "Group Agency, Responsibility, and Control," Philosophy of the Social Sciences 43 (2013): 201-24. 
and even changes in political regimes, modern states (or at least some of them) are prime candidates for long-lasting irreducible corporate moral agency and responsibility. Their constitutions typically include principles of governance, institute multilayered decision-making procedures, and impose the kinds of balances and checks necessary to foster relative organizational autonomy and sufficient rational consistency over time. Common examples of relevant decisional constraints include the separation of powers between the executive, the legislative, and the judiciary, bicameral legislatures, judicial review of administrative and legislative action, stare decisis, enforceable bills of rights, elections, federal division of powers, constitutional conventions such as ministerial and cabinet responsibility, impeachment procedures, and the like. No doubt, modern states depend on their individual members to make decisions and act, but by committing and adhering to their state's constitutional framework to a reasonable extent, such individuals can bring about genuine state moral agency and responsibility. Indeed, for List and Pettit, states qua corporate agents may even appropriately be described as persons, insofar as "person" is understood in the sense of an agent capable of appropriately responding to reasons, and performing in the space of obligations. ${ }^{8}$

As controversial as this and previous claims may be, ${ }^{9}$ I will henceforth assume, arguendo, the soundness of the account to this point. That is, even if we accept that some states are irreducible group agents, or persons, and can be responsible for, say, unjust or otherwise wrongful actions and be blamed for them, can these states also be liable qua groups to adverse consequences? In other words, can their moral agency, or performative personhood, not only make them susceptible to judgments of responsibility and blame, as is often alleged, but also to liability, including liability to attack?

\section{State Corporate Liability to Attack? \\ a. Liability to Attack}

The idea of liability to attack is central to much individualistic Just War theorizing. ${ }^{10}$ At its core lies the thought that, if one is liable to attack, one is not wronged

8. List and Pettit, Group Agency, chap. 8. They defend this account of personhood against accounts grounded in phenomenal consciousness, which, they concede, would not extend personhood to corporate agents.

9. Jeff McMahan himself rejects them: "Aggression and Punishment," in War: Philosophical Perspectives, ed. Larry May (Cambridge: Cambridge University Press, 2008), 67-84, at 83.

10. For an extended discussion of moral liability in this volume, see Richard Arneson, "Resolving the Responsibility Dilemma." See also Jeff McMahan, "Liability, Proportionality, and the Number of Aggressors." 
by it, and may not complain about it on that basis. Liability so understood is not a justificatory panacea: it is neither a necessary nor a sufficient condition for the permissibility of attacking someone. For example, it may be wrong to attack a person who is liable to it insofar as it would wrong others, who would be harmed as a side effect. It may also be permissible to attack those who are non-liable, say, as a means of preventing substantially worse harm. Still, establishing that one is liable to attack is a distinctive and important step in an overall argument about the permissibility of attacking him or her.

How is liability established? Accounts diverge. For McMahan, liability corresponds to the loss or, more precisely, the forfeiture of a right. A "person's being liable to attack," he contends, "just is his having forfeited his right not to be attacked, in the circumstances." ${ }^{11}$ Thus, one's liability to attack arises through some action-some responsible act or omission. Usually, McMahan argues, such liability arises through action that constitutes responsible wrongdoing - most notably, the responsible posing of an unjust threat of harm. Although an aggravating factor, culpability is not required for liability, as in the case of the homeowner who mistakenly threatens to shoot the identical twin of a mass murderer, known to break into people's homes and kill them on the spot, when the twin brother shows up at his doorstep. Despite being excused for his wrongful threat, McMahan holds, this homeowner is liable to defensive attack. Yet liability is importantly not an all-or-nothing affair. For example, it would wrong a person who is morally responsible for an unjust threat if he or she were merely attacked for fun, or simply because attacking them would do more good than harm in a way that bears no relation to their wrong. A person is liable to attack, McMahan insists, only when attacking this person is necessary for the prevention or correction of a wrong for which the person is morally responsible, and the harm that the attack would cause this person is not excessive in relation to the realization of one of those aims. Still, in war, where unjust threats will often be to individuals' lives, and be overly burdensome or impossible to avert without seriously harming or even killing those responsible for them, attackers may well be liable to such a fate.

Others, like Victor Tadros, conceive of liability more expansively. Like McMahan, Tadros thinks of it as tethered to preventive or corrective goals, and as coming with internal necessity and proportionality constraints. Still, according to him, the concept does not so much track the loss of rights as situations in which one does not have a right in the first place. The most important way in which one lacks a right not to be attacked for the sake of some relevant goal is, he

11. McMahan, Killing in War, 10. 
suggests, when one has an enforceable duty to bear the harm that would result from the attack, for the sake of that goal. ${ }^{12}$ Assume, for example, that one has a duty to rescue a child drowning in a pond at a minimal cost to oneself-say, incurring a bad cut on one's leg that will leave a visible scar (or perhaps even, per Tadros, losing a finger) - but that one is unwilling to do so. Assume further that the child could be rescued by throwing the unwilling person into the pond, and that this attack would only cause the person to incur the said minimal cost. Tadros argues that the unwilling person is liable to this attack. She is liable to it in the sense that she has an enforceable duty to rescue the child and, accordingly, has no right not to be harmed in this way for the sake of the child. When the stakes are higher, one may also be liable to much more than such a minimal cost. For example, Tadros contends that, were someone the only person able to save a very large number of lives, he may have an enforceable duty to do so at the cost of his life. Were he unwilling or unable to discharge this duty, he would then be liable to be killed as a means of saving the other lives at stake, even though he is not responsible for what is threatening them.

Culpability without responsibility can also ground liability to attack for Tadros. Consider the following hypothetical:

Evelyn hires a hitman to kill Wayne. Fred also hires a hitman to kill Wayne. Both hitmen arrive at the same time. Because of where they are standing, Wayne can only use Fred as a shield against Evelyn's hitman and Evelyn as a shield against Fred's hitman. He manages to do that, resulting in the deaths of Evelyn and Fred. ${ }^{13}$

Tadros contends that it is permissible for Wayne to use Evelyn and Fred in this way, given that they are both liable to it. Since Evelyn culpably chose to set her murderous threat in motion, she has a duty to prevent Wayne from being killed by it, even at the cost of her life. So does Fred. Still, by hypothesis, neither can discharge this duty by themselves, such that each has a derivative duty to try to get someone else to do it for them. Tadros argues that since each can avert the threat that he or she culpably created by forming and executing an agreement with the other, to the effect that he or she will avert the threat that the other has created, each has a duty to do so. If either or both are unwilling, Wayne can do to them what they have a duty to do. That is, he can use the two as shields to avert the

12. See Victor Tadros, "Duty and Liability," Utilitas 24 (2012): 259-77.

13. Victor Tadros, The Ends of Harm: The Moral Foundations of Criminal Law (Oxford: Oxford University Press, 2011), 192. 
threats that he faces even if, in so doing, he harms each of them as a means of averting a threat that he or she is not responsible for creating.

Tadros does not deny McMahan's contention that one's moral responsibility for an unjust threat can engender one's liability to attack, including liability to be seriously harmed or even killed in the process. However, since he believes that liability rests on enforceable duties to bear harm, and that such duties can be grounded in many other considerations than moral responsibility, his conception is more expansive and multifaceted. For him, considerations of beneficence and culpability can also ground liability to attack quite independently of considerations of moral responsibility, and so might considerations of causation and benefit. ${ }^{14}$

Here is not the place to adjudicate between these two leading accounts of liability. More would need to be said about them, and perhaps other contenders, before any sound verdict can be reached. Still, I believe that the two are sufficiently representative to allow for a meaningful discussion of the issue of corporate (group, collective) state liability to attack.

\section{b. The Basis for Extending Liability to Attack to States}

To recap, it follows from the account of corporate agency considered that states that meet relevant organizational criteria can have reasons, including duties-of beneficence, justice, not to harm, etc. - that apply to them qua groups, and to which they can respond appropriately qua groups. When they fail to do so, they, like other moral agents, may be responsible for wrongdoing (understood as a breach of duty). In the context of war, such wrongdoing might include the creation of unjust threats of harm. Since, as group agents, states can make choices and plan for action and, in so doing, may exhibit irreducible attitudes such as intentionality, recklessness, or negligence, they may even culpably give rise to such wrongful threats.

Moreover, it seems to follow from the account that, as corporate entities with goals of their own for which things can go well or badly over time-and, thus, which can plausibly have interest ${ }^{15}$ — states may also conceivably have rights. They may have rights in the sense of interests sufficiently important to ground

14. Tadros, "Duty and Liability," 269-77; Victor Tadros, "Causation, Culpability and Liability," in The Ethics of Self-Defense, ed. C. Coons and M. Weber (Oxford: Oxford University Press, 2016).

15. On organized group agents as interest holders, see further Rachael Briggs, "The Normative Standing of Group Agents," Episteme 9 (2012): 283-91. 
duties in others. ${ }^{16}$ One common objection to this claim is that groups should never be thought to have any moral value prior to, or independent of, the good or interests of their individual members. Thus, their rights should not be ascribed any value per se. Assertions to the contrary, the objection typically goes on, served as normative entry points for some of the worst Nazi and communist atrocities of our times. They did so by paving the way for arguments that the corporate rights of groups, understood separately from those of individuals, could simply trump them. ${ }^{17}$ While alluring, this (rather crudely formulated) objection does not undermine the possibility of morally important corporate rights that are irreducibly held by states. One possibility is that, though important, corporate rights, however valued, are always less stringent than individual rights, or at least less stringent than core individual rights to life, against torture, not to be harmed, and so forth, which are characteristically at stake in war. Another possibility is that, while corporate rights, however valued, might at times defeat important individual rights, they did not do so, contrary to what was alleged, in the specific historical circumstances contemplated by the objection.

List and Pettit opt for a different line of argument that is more aligned with familiar liberal or republican commitments. They reject outright that the rights and interests of organized groups can ever be valued independently of those of individual persons. After all, they claim, such groups are merely social arrangements that individuals create and maintain, through coordinated efforts, to serve social ends, and it would seem somewhat circular to factor in these groups' own interests when assessing their value. That is, List and Pettit's account allows for the possibility of corporate rights while endorsing the widely shared principle of value individualism, according to which the worth of corporate agents (and, indeed, of anything else) must ultimately be appreciated in terms of their contributions to human (or, at least, sentient) life and its quality. ${ }^{18}$ Their point, I take it, is that to meet the common objection, an account of state corporate rights can make clear that the moral value and strength of these rights may only be derived from how they serve individuals' good or interests-even if only in a mediated

16. On this understanding of rights, see Joseph Raz, The Morality of Freedom (Oxford: Oxford University Press, 1986), chap. 7. As Raz himself recognizes, one is capable of having rights in this sense "if either his well-being is of ultimate value or he is an 'artificial person' (e.g. a corporation)" (166). Note that, unlike Raz, I do not claim here that individual human beings have no rights grounded in other considerations than interests.

17. See further David Rodin, War and Self-Defense (Oxford: Oxford University Press, 2003), $143-44$.

18. List and Pettit, Group Agency, 182; Christian List and Philip Pettit, "Episteme Symposium on Group Agency: Replies to Gaus, Cariani, Sylvan, and Briggs," Episteme 9 (2012): 293-309, at $307-8$. 
and irreducible way. ${ }^{19}$ Consider the oft-discussed irreducible rights of states against the interference of external actors in their internal affairs, namely, their sovereignty rights. States plausibly have such rights, at least in part due to their interests in developing and seeing through their group plans. Insofar as they do have such rights, they also plausibly have some moral stringency. However, when it comes to assessing it, value individualism ought to take center stage. For example, the rights' stringency may be evaluated based on the desirability, for individual members, of seeing their state's group plans realized given the importance of collectively organized territorial governance that is close to the governed and, in our morally plural world, can better reflect and support the development of valuable local understandings, cultures, and traditions. Furthermore, insofar as there are no other entities able to govern as effectively and impartially, and secure important public goods such as these and others, failure to recognize states' sovereignty may be quite counterproductive for individuals. External meddling may result in all sorts of harmful mistakes and abuses that make things far worse for them.

Such theoretical refinements should go some way toward assuaging the concerns of individualistic theorists who are reminded of traditional Just War theorists' "domestic analogy," according to which states are analogous to individual persons, and are governed by the same moral principles as them. ${ }^{20}$ Recall, though, that this analogy never comes alone for Just War traditionalists. They also think that war occurs primarily between states, and that it is primarily morality as it applies to them that governs it. Consequently, individual participants in war are largely eclipsed from key aspects of their theories. Taking their view seriously seems to entail that individuals are, at most, embodiments of their states, and the harms they suffer are, at most, non-lethal harms to the larger collective entity. For individualists, a key problem with such reasoning is that, while we may intelligibly say that attacks on states can wrongfully "harm them"-in the sense of violating "their rights" or otherwise setting back "their interests" — such talk is at most metaphorical and dangerously so. It is dangerous insofar as it is taken as a basis to argue that it is the rights and interests of states qua distinct persons that should be morally commanding in war, as opposed to those of individuals. Surely, individualists counter, wartime attacks on states generally involve the killing and serious harming of individuals, and these facts are sufficiently important not to be disregarded in favor of an exclusive focus on states, or unduly discounted as mere

19. See further Dwight Newman, Community and Collective Rights: A Theoretical Framework for Rights Held by Groups (Oxford: Hart Publishing, 2011), esp. chap. 5.

20. The expression is used by Walzer in Just and Unjust Wars, 58 . 
expendable parts of them. ${ }^{21}$ I find this rejoinder compelling. If attacks on states are to be justified in terms of state liability, the explanation for it must give individuals' rights and interests their due.

So, for some individualists, List and Pettit's suggestion that states can be real, as opposed to metaphorical, corporate agents-even persons-with important irreducible duties and rights will likely trigger alarm bells. Still, the latter's account can avoid traditionalist oversimplification. Pace List and Pettit themselves, it may perhaps even do so by recognizing the non-circular possibility of some non-individualist valuation of corporate states and their rights-some may prefer to speak of impersonal value. ${ }^{22}$ It may, insofar as it also clarifies how such valuation can relate to individuals' distinct rights and interests without denying them their proper stringency. Admittedly, the idea of impersonal collective valuationindependent of how human lives-in-being (or, at least, sentient beings) are affected by the collective object of value-remains philosophically fraught, especially among self-proclaimed individualists. So this suggestion will likely meet significant resistance. Note, however, that the account can also avoid traditionalist oversimplification by unwaveringly holding onto the received wisdom of value individualism, as List and Pettit themselves suggest and as I will assume from now on. I do so both for the sake of simplicity and as an attempt at rapprochement with individualists, but also because I believe (though cannot argue here) that even if some states have impersonal corporate value, this value is likely insignificant as compared with the value of individual interests generally at stake in wars, such as life and bodily integrity.

Thus, following List and Pettit, states qua group agents can have irreducible rights, but these rights may be lost, or otherwise run out, in virtue of how states relate to individuals. ${ }^{23} \mathrm{~A}$ state may, for example, have no sovereignty-based complaint against various types of external interferences aimed at thwarting its

21. See especially Jeff McMahan, "What Rights May Be Defended by Means of War?" in The Morality of Defensive War, ed. Cécile Fabre and Seth Lazar (Oxford: Oxford University Press, 2014), 115-56.

22. Think, for example, of their aesthetic value in the abstract. See further Derek Parfit, Reasons and Persons (Oxford: Oxford University Press, 1984).

23. Incidentally, such value individualist thinking about the relative moral importance of states qua group agents goes some way toward addressing Marko Milanovic's query, which Larry May highlights in his contribution to this volume. "If human rights accrue to human beings solely by virtue of their humanity," Milanovic asks, "why should these rights evaporate merely because two states [...] have engaged in armed conflict?" Insofar as value individualism is true, even if states are distinct moral agents with rights of their own, these must always be understood in terms of how they serve the rights of individuals, and never as unrelated substitute for them. In other words, human rights remain at the heart of the morality of war, in spite of states' involvement. 
violations of its individual members' human rights. ${ }^{24}$ It may also have no justified sovereignty-based complaint against some external interferences aimed at averting its unjust threats to foreign populations. May we then intelligibly hold that a state is, qua corporate entity, liable to such interferences? It seems to me that we may.

\section{The Moral Salience of State Corporate Liability to Minimally Harmful Targeted Attacks}

An important tension here is that a state's corporate liability to an external interference does not entail that individuals, who may be harmed in the process, are also liable to it. Such individuals may not be morally responsible in any way for the unjust threat that gives rise to their state's liability. Neither may they be causally responsible or culpable for it, or even beneficiaries of it. Still, this objection is contingent. Some external interferences aimed at averting a state's unjust threat may be sufficiently well tailored to impact only what is irreducibly the state's own-namely its decisions, plans, policies, and their materialization-without harming individuals, or only occasioning negligibly small harm to them. Think of some sufficiently well-designed arms embargoes geared at thwarting a state's aggressive intentions. Or consider foreign tanks temporarily crossing an aggressive state's border, or military aircrafts flying into its airspace, in a preventive show of force. Think also of more invasive targeted bombings of unmanned weaponsstorage or missile-launching facilities, or of empty military airport runways soon to be harnessed for unjust offensives. All else being equal, ${ }^{25}$ state corporate liability to such incapacitating or otherwise preventive interferences-which, note, include attacks - may not only be intelligible, but also morally unproblematic.

An important payoff of recognizing the possibility of such liability is tied to the eventuality that a state's unjust threat may emanate from an irreducible decision. Remember the kind of multi-premise majority decision-making discussed above. Imagine that, when votes on successive issues are aggregated, they yield a corporate plan to launch an immediate unjust offensive that no individual actually endorses. Imagine further that no individuals, either voters or enactors of the states' plan, are sufficiently responsible for it—let alone culpable or benefiting — for their liability (assuming they have any) to be determinative of the permissibility of a

24. For two of many versions of this claim, see Joseph Raz, "Human Rights without Foundations," in The Philosophy of International Law, ed. Samantha Besson and John Tasioulas (Oxford: Oxford University Press, 2010), 321-37; Christopher Heath Wellman, "Debate: Taking Human Rights Seriously," Journal of Political Philosophy 20 (2012): 119-30.

25 . By this I mean, in part, that harm to individuals occasioned by the interference would be, at most, negligibly small. 
circumscribed yet necessary preventive attack of the kind just suggested. In such limited cases, their state's liability to attack might ground the relevant permission.

Some may be tempted to recharacterize this permission in terms of a liabilityless "lesser evil" justification — say, because bombing the would-be aggressor state's military runway or weapons-storage facility would save many lives. This view has the appeal of simplicity. However, I believe there are at least two reasons why the possibility of morally salient state corporate liability should not be discarded. First, it will not always be unambiguous that bombing unmanned runways or storage facilities is a lesser evil. It may not be if, for example, such defensive bombings are carried out to prevent the unjust destruction of military installations or other state property whose value is, all things considered, not obviously greater. In such situations, state corporate liability may be a morally salient fact that helps fix the parameters of permissible preventive attacks on the unjustly threatening state. Second, lesser evil reasoning may be articulated without any attention to the involvement of irreducible state agency in the creation of unjust threats. Insofar as a group agent is, in fact, a source of such threats, and such behavior affects its moral standing, subtler moral reasoning that reflects it is likely preferable.

Others, still, may question the point of recognizing state corporate liability from the angle of redundancy. They may contend that the voters and enactors of the state's unjust threat in my scenario have really brought this threat about jointly, irrespective of whether their actions ultimately translated into those of an irreducible corporate agent. If, indeed, they are jointly responsible for the threat, they may also be jointly liable for it. Could such joint liability not play the limited demarcation role that I have so far been ascribing to state corporate liability, in relation to non-harmful attacks on military facilities? Here are some grounds for doubting it. First, to be successful, this move would require a sound account of how the joint liability of some individual decision-makers and enactors implies the permissibility of destroying state property. Even if such an account can be provided-say, through arguments from representation or trusteeship_-joint liability may still not exhaust the space of state corporate liability. By hypothesis, no individual voter in my scenario intended the unjust threat, and all may have actively opposed it. Thus, it is hard to conceive of such voters as intending or desiring that they together bring about the unjust threat, a condition commonly deemed necessary for non-corporate joint action and responsibility. ${ }^{26}$ Assuming

26. See, e.g., Michael Bratman, "Shared Agency", in Philosophy of the Social Sciences: Philosophical Theory and Scientific Practice, ed. Chris Mantzavinos (Cambridge: Cambridge University Press, 2009), 41-59; Philip Pettit and David Schweikard, "Joint Actions and Group Agents," Philosophy of the Social Sciences 36 (2006): 18-39. One may wonder whether voters intending or desiring that they together bring about $a$ decision on a given set of issues is sufficient to ground their joint agency and responsibility in respect of what is actually decided. While I doubt it, I cannot provide a defense here. 
that no one vote would have made a difference, there may also be relevant issues of causal overdetermination in respect of each voter. Let us also stipulate that none of them would benefit from the threat in any significant way. Finally, for the sake of simplicity and effective exposition, let us assume that, in the state in question, a quick-reaction electronic system is in place to compute the votes and give immediate effect to time-sensitive operational military plans such as the one decided upon - say, by initiating, without further human intercession, the targeted launch of automated missiles. Though farfetched, this last set of facts avoids muddying the example with distracting questions of individual liability that could arise from the responsibility or culpability of enactors of the plan. Along with the voting scenario described, this hypothetical specification helps show that, in some conceivable though limited cases, state corporate liability might have a morally salient role to play.

\section{Fleshing Out Individualists' Powerful General Objection to State Corporate Liability}

Now, despite what I said in the last section, preventive military action against a state will almost always involve the deliberate killing or severe harming of individuals, on a significant scale. After all, this is what we have commonly come to mean by "war"-likely because, most often, it is hard to imagine bringing a state to desist from unjust aggressive designs by means of attack without harming at least some of its individual members. The key individualist objection to the moral salience of state corporate liability in this context can perhaps most clearly be articulated in terms of Tadros's understanding of liability. Underlying my earlier description of his account is Tadros's attempt to meet the nonconsequentialist objection against intentionally using — or worse, harmfully using—individuals as a means to achieve some good. This important objection is generally defended on the basis of individuals' ultimate value as beings independent from each other, who each have an intrinsic right to set their own ends. It is in response to this objection that Tadros contends that individuals can permissibly be harmfully used if they have enforceable duties — and, thus, are liable — to bear harm for the sake of some goal. Admittedly, List and Pettit do argue that corporate agents are relatively independent, or autonomous, from their individual members. However, nowhere do they even speculate about the possibility of such agents' ultimate valuation; their commitment is to value individualism. Insofar as they are correct (or that the impersonal significance of states is comparatively trivial), it would seem paradoxical to claim that states qua group agents can have morally salient enforceable duties to sustain attacks, when those who are targeted as means of enforcement are mostly their individual members, often at the cost of their lives 
or bodily integrity. Shouldn't the inquiry be the other way around, focusing instead on ultimately valuable individuals and their liability, as opposed to the liability of an entity whose value is derivative from theirs (or is otherwise too insignificant to play any salient role)?

The point can also be made in McMahan's idiom by emphasizing that, while it may sometimes be consistent with value individualism for corporate rights (and their loss) to take priority over specific individual rights, such prioritization is only permissible when it better serves individuals' interests or good otherwise understood. Prioritizing corporate rights and their loss when assessing the permissibility of attacks targeting individuals is likely to do precisely the reverse, since a state's forfeiture of sovereignty rights may well not automatically entail that targeted individual members also lose their individual rights not to be harmed. To know whether they do, we need a more particularized approach to determining the permissibility of attacks that tracks individuals' liability and its grounds.

Again, individuals' liability is not a justificatory panacea. If, as in cases of attacks targeting what is the state's own, some individual members end up being harmed or killed as unintentional side effects, the salient moral question may be whether these individuals' rights could permissibly be overridden, or otherwise delimited, for the sake of some intended greater good. I am also not denying the possibility that such greater good may sometimes be irreducibly collective in nature - think of the value of a just or a solidaristic community — and that it may be entwined with the existence of states qua corporate agents. Notice, however, that the point about overriding is not a point about liability so much as a point about competing values. Nor is the following point so much about states' corporate liability as it is about group values and their importance. Given the limited focus of my inquiry on state corporate liability, it seems methodologically important to keep these distinctions in mind.

Should my conclusion then be that, while state corporate liability to an attack may be morally relevant to its permissibility when the attack does not involve harm to individuals, or perhaps no significant harm to them, it is irrelevant or, at most, overshadowed by individual considerations when it does? List and Pettit's account of corporate agency would not stand in the way of this conclusion. Unlike traditionalist collectivist accounts, their argument does not preclude assessments of individual liability arising from what individuals do in making state corporate agency possible, or otherwise. Thus, some voters in my earlier scenario may have intended to bring about the unjust threat, and done everything they could to ensure its materialization. Given their actions, not only in voting but also in convincing others, they may, at least partly, have been morally and causally responsible, even perhaps culpable, for this unjust threat. In light of the importance of the threat, they may even have been liable to defensive attack. Military enactors of 
the threat may, too, have been liable in virtue of their responsible and culpable contributions. If that is correct, our next question must then be whether a state's corporate liability can ever add anything salient to the individualist moral picture when assessing the permissibility of deadly or significantly harmful attacks in war.

\section{A Limited Democratic Rejoinder?}

Could it be, for example, that, in respect of at least some states that meet the conditions of group agency, their corporate liability may ground individual members' liability to attack in a general way? The suggestion is not new, although some of its more famous articulations blatantly fail to meet the individualists' objection. Think here of Rousseau's controversial contention that only the democratic state remains once the social contract that creates it is entered into by the multitude of individuals, such that, by definition, the state's collective will is also the will of each individual member. ${ }^{27}$ Given this blunt conflation, it is unsurprising that Rousseau holds that "war is then not a relationship between one man and another, but a relationship between one State and another, in which individuals are enemies only by accident ... any State can only have other States, and not men, as enemies." 28

There are more nuanced versions of the democratic proposal. For example, in his recent work on non-domination, Philip Pettit himself suggests that while a state can be a responsible corporate agent in its own right, its individual members can also aspire to control it jointly. ${ }^{29}$ They can aspire to do so in domains in which our world's existing arrangements allow states at least some discretion as to action, and in a way that makes individual members' share in the joint control equal. For such equally shared joint control to obtain, a number of conditions must be met. Crucially, individual members, enabled by a suitable constitution, must exercise equally accessible, unconditioned, and efficacious influence over the state, which pushes it to act in a direction equally acceptable to all. The overall claim is that, when such conditions are met, individual members actually control their state's will, even if they leave matters of detail to the corporate luck of the draw. This argument may have implications for liability. Could we not hold that individual members of such a democratic state would have no justified complaints against their state being subjected to a bloody attack aimed at preventing its unjust threat,

27. Rousseau, The Social Contract, I.6, II.12.

28. Rousseau, The Social Contract, I.4.9.

29. Philip Pettit, On the People's Terms: A Republican Theory and Model of Democracy (Cambridge: Cambridge University Press, 2012), chaps. 3-5. 
given that its liability to it must, in a very real sense, also be theirs in an equal measure (in virtue of their equal joint control)?

The idea that control of a liable agent entails the controllers' liability is a multifaceted one that I cannot unravel here. Instead, let me point out a number of key difficulties with the argument that are especially relevant to my inquiry. These difficulties exist over and above the obvious criticism that no existing state comes even remotely close to meeting Pettit's desiderata of popular control. In all current so-called democracies, popular control is limited and unequally exercised, such that control-based generalizations about liability are morally hazardous. Still, since Pettit's conditions are explicitly meant to be achievable, let us take him at his word for the sake of argument. ${ }^{30}$

Note, first, that if a state's individual members actually control it, and this control gives rise to their liability to attack, then the key to the permissibility of the attack seems to be their joint individual liability, not their state's corporate liability. As Pettit makes clear, there is a distinction between the unincorporated plurality of citizens who jointly seek to control their state, and the state qua selfgoverning singular corporate entity that they may not succeed in controlling. ${ }^{31}$ If, when they do not control their state, they are not liable for its wrongs and, when they do control it, they are liable for them, it seems to be their control-derived liability, not their state's liability, that is operative.

Second, the fact that an individual member has as good an opportunity as all others to exercise some control over his state does not mean that he actually controls it (or even that he has a consistently effective ability to do so). This point holds true even if, as Pettit suggests, there is a system of contestation in place that allows individuals to test state decisions for how the process in which they are generated respects the value of equal access to influence. For if the state ultimately does things that one bitterly and proactively opposes-for example, launches unjust military offensives-one must surely regard them as things one does not control. Arguably, what Pettit has in mind is joint popular control of the general direction of a state's actions over time, where each individual member might "win some" but also "lose some." However, what if one of my "losses" relates to my state's one-off creation of a serious unjust threat to the population of another state? Would my share in the control of my state's otherwise nonbelligerent direction suffice to make me liable to be harmed, and possibly killed, to avert this threat? Assuming that I lack any other relevant responsibility, culpability, and so forth, for the threat, and would not even benefit from it, it is intuitively doubtful. This,

30. Ibid., 180.

31. Ibid., $285-88$. 
I believe, is because it is such facts about me qua individual that remain morally commanding. Our intuitions may be somewhat different when a state's popularly controlled general direction is one of unjust belligerency. However, even if, in such a case, we can accurately say that this direction is controlled by all, my earlier point still holds. Joint individual liability may provide all the explanation we need.

Note, finally, that Pettit's control argument is explicitly limited to adult, ableminded, and more or less permanent residents of democratic states. Children, visitors, and those who are genuinely unable to control their state are excluded $a b$ initio. ${ }^{32}$ Therefore, assessments of the permissibility of attacking them must proceed separately from any general control-based arguments about joint or corporate liability, if their rights are not to be unduly disregarded.

Then again, I may have unfairly stacked the deck against the relevance of state corporate liability to lethal or significantly harmful attacks by focusing on a suggestion that rests on individuals' actual control. Indeed, a similar worry also arises in respect of all arguments grounded in individuals' voluntary choice to join a state or in their actual consent, explicit or tacit, to accept responsibility for its actions. Since, typically, not every member of a state will have so chosen or consented, let alone have had a genuine opportunity or otherwise been able to do so, individualized assessments would still be called for and ready generalizations remain questionable. Notice, however, that this kind of objection may not hold as firmly against arguments based on what is sometimes referred to as "necessary popular authorization." If, for example, one were able to argue successfully that no individual member could reasonably oppose their corporate state's actions, because they generally could or should not do without them, then it may be possible to maintain that when the state's corporate liability is engaged, theirs also is ipso facto.

Consider, as a way of orienting our thinking, the following proposal, inspired by aspects of the Kantian and broader republican traditions, which I have broken down into deliberately rough and suggestive premises. I offer it, without being committed to it, as a provocation that may help us see how such an argument could unfold:

(1) Justice as individual independence. The ideal of justice corresponds to social conditions in which each individual is treated with the respect with which she should be treated. According to one prominent version of this view, justice prevails when each is treated as an equally valuable independent

32. Ibid., 138. 
being who may set her own ends for herself, unless she does so in a way that is inconsistent with equal independence for all. ${ }^{33}$

(2) Corporate state agency as required for justice. Given the difficulty of bringing about and maintaining such a condition in every relevant aspect of individuals' lives, the coordination of a state qua corporate agent is required. Such a state is required for justice, since the many complex, interconnected, and dynamic tasks necessary to make it possible could not be discharged by any one individual or by an unorganized plurality, even with the assistance of an impersonal apparatus of disciplining rules and routines. The tasks in question include establishing and adjusting just laws that, among other things, identify substantive and coherent basic liberties; ensuring that sufficient resources and adequate infrastructures are in place to sustain everyone's independence; protecting people against the invasion of their independence, whether in particular relationships or on a more general front; and so forth. What is needed to discharge such tasks is a state (or whatever else one may want to call it) qua collective agency, made up of numerous specialized officials and subsidiary agencies, yet speaking with a unified voice, acting to a coherent set of ends and, insofar as it fails, remaining sensitive to the need to restore harmony. To be effective, this state also needs to have the power to secure coercively the order it establishes, as well as a recognized claim to exclusive authority to govern it. $^{34}$

(3) The high value of justice. Justice is extremely valuable given that a life lived under the subjection of another's private will (think of the life of a slave or of an ongoing victim of torture), or even the ongoing threat of subjection to it (think of life in the state of nature), is a critically impoverished life. ${ }^{35}$

(4) Individual members' stringent duty of justice to support and own up to the state's endeavors. Therefore, for their own sake and the sake of others, individual members of a reasonably just corporate state all have a stringent (and, arguably, enforceable) duty to support its endeavors, plausibly at considerable costs to themselves. They have such a duty insofar as their state's interpretation and rendering of justice is reasonable. This last proviso is necessary since reasonable mistakes are an inevitable concomitant of moral agency in our world, and the value of a reasonable approximation of justice may more than make up for such deviations.

When such a reasonably just state launches an unjust offensive against another state on the mistaken, yet understandable assumption that it is necessary to defend its

33. For a detailed articulation of this view, see Arthur Ripstein, Force and Freedom: Kant's Legal and Political Philosophy (Cambridge, Mass.: Harvard University Press, 2009).

34. For a defense of this position, see Pettit, On the People's Terms, esp. 132-36.

35. Again, see Ripstein, Force and Freedom. 
internal order and individual members, the argument so far may seem to invite the conclusion that the latter are liable to share in the costs. While their state may clearly be deprived of a right against forceful interference as a result of the offensive, they, too, as a result, may generally be deprived of their right against attack. They may be so deprived on account of their duty to support and own up to their state as an enabler of justice, when it succeeds as much as when it reasonably errs.

Interestingly, those who otherwise defend state corporate liability on similar lines tend to deny, often without saying much more, that the kind of argument considered can successfully ground a general liability as severe as a liability to harmful attacks. ${ }^{36}$ Why? One might think that, on its own, the general duty to support the conditions of justice-in the form of a state qua corporate agent-is not sufficiently important to ground a general liability to be killed or seriously wounded. Indeed, recall that, by hypothesis, individual members may not have consented to (or been able to consent), voluntarily affirmed, or otherwise identified with the state or its wrongdoing, and may not have had any responsibility for or culpable connection to the existence or subsistence of either. Still, is it really so implausible to think that justice, itself so valuable to human life in society, can, at least sometimes, be sufficiently important on its own to ground individuals' general liability to attack-whether the value is understood as in (1) or, expansively, to include the coordination and distribution of resources with a view to elevating individuals beyond minimally decent conditions of well-being, or even as also having some impersonal value? Furthermore, even if justice so understood is not sufficiently important on its own, could it not be so, at least sometimes, when coupled with other important public goods the realization of which depends on states' corporate agency ? $^{37}$

The key point to make here is that, even if a plausible argument to this effect could be developed, other even more formidable obstacles stand in the way of the line of argument considered. One relates to the premise that, in today's world, justice and other relevant values depend for their realization on the corporate agency of organizations akin to those I have been referring to as corporate states.

36. See especially Anna Stilz, "Collective Responsibility and the State," Journal of Political Philosophy 19 (2011): 190-208. At one point, Stilz seems to claim that individual state members cannot permissibly be harmfully targeted in response to their state's harmful wrongdoing insofar as they are not individually to blame for it. As we have seen, though, blameworthiness tends not to be regarded as a condition sine qua non of liability to attack. On the state being constitutive of what justice requires, see further Anna Stilz, "Authority, Self-Determination, and Community in Cosmopolitan War," Law and Philosophy 33 (2014): 309-35.

37. Cf. John M. Parrish, "Collective Responsibility and the State," International Theory 1 (2009): 119-54. 
If, alternatively, an individual Hobbesian-like sovereign or, say, individuals acting through states (or other organizations) with no corporate agency of their own can realize these values, or if no organizations whatsoever are required to realize them, then the part of the argument that rests on state corporate agency becomes superfluous. In other words, the argument may only be misleadingly tethered to the corporate idea with which I have been concerned. Individuals' general liability to attack may still arise, at least in part, from their membership in a given state, but contentions to this effect might then be able to sidestep altogether the corporate question. ${ }^{38}$

In the end, though, even if a claim about state corporate agency and justice like the one in (2) can withstand close scrutiny, an even more germane objection remains: is the line of argument considered really one about state corporate liability at all? Is it not instead an argument about when state corporate injustice or other relevant state action may partake in grounding individuals' liability to attack? Arguably, (4) betrays this fact by suggesting that if state corporate liability ipso facto engages individual members' liability, it is because they have a strong and potentially enforceable duty to support and own up to the endeavors of their reasonably just state. The question then arises of whether the idea of state corporate liability to attack does any salient moral work, over and above its tracking of individuals' liability. While, as I suggested earlier, the answer may sometimes be affirmative in cases where individuals are not at risk of being significantly harmed by an attack on the liable state, the reverse seems to be true when significant individual harm is at stake. In such contexts, even if state corporate agency may constitute an important premise in liability assessments (say, as an alleged condition of justice), it is individuals' duties and rights that seem to remain commandingjust as individualist theorists claim they should be.

This worry may well be fatal to the prospects of a salient moral category of state corporate liability to (most) attacks in war. Compound it with the other controversies mentioned, as well as with the fact that the line of argument considered is strictly limited to states of a certain type (i.e., reasonably just corporate states), and the relevance of the category seems ever more questionable (at least when significant harm to individuals is at stake). Could this conclusion be the price to pay for accepting individualists' core insight against Just War traditionalists, and for refraining from departing from value individualism in unacceptably radical ways? I am tempted to think it is.

38. Prominent arguments adopting this strategy include Frances Kamm, "Failures of Just War Theory," in The Moral Target: Aiming at Right Conduct in War and Other Conflicts (Oxford: Oxford University Press, 2012), 36-80, at 64-72; Tadros, "Duty and Liability," 271-77. 


\section{Conclusion: The Wider Relevance of State Corporate Agency}

Thus, even if it is intelligible and may otherwise be morally useful, the idea of state corporate liability seems, at most, of very limited relevance to the morality of war. This conclusion will likely please many individualist theorists-including those who think that, although it matters that wars are not fought by lone individuals but groups of them, individualist concepts such as individual complicity, vicarious individual liability, individual associative duties, and joint individual liability are sufficient to account for attendant moral complexities. Still, even if my conclusion and analysis are correct, these theorists should not be too quick to claim victory. State corporate agency and responsibility may still have an important role to play in the morality of war. An important upshot of my discussion, I believe, is that it not only helps identify what this role is not, but also orient where we should look next.

For one thing, if, as queried above, some values of great importance can only be realized through the intercession of corporate agents, such values may ground important duties in individuals to constitute, support, and influence these agents-and correspondingly limit these individuals' rights. Insofar as the said duties are enforceable, the question may then be asked whether they may be enforced through attacks in war. Here, the issue is clearly one of individual liability, as opposed to corporate liability, but it remains intrinsically connected to the possibility and value of corporate agency. The line of argument sketched in the previous section is only one of many conceivable arguments that merit further exploration along such lines. ${ }^{39}$

Furthermore, if states qua corporate agents can perpetrate wrongs that are distinctively their own, then a question arises as to whether individuals may participate in such wrongs in ways that enhance their individual liability. The suggestion is sometimes encountered that individuals' wrongful complicity in corporate wrongdoing can be distinct from wrongs these individuals perpetrate as principals, when contributing to corporate agents' decisions and their implementation. ${ }^{40}$ No doubt, even if this suggestion is correct, some difficult work remains to be done about how to differentiate properly accomplice from principal wrongdoing, especially in the context of single individual actions enacting corporate decisions.

39. Much insightful work on individuals' duties tied to the possibility of corporate agents is currently being developed, and may usefully be applied to the Just War theory context. See especially Stephanie Collins, "Collectives' Duties and Collectivization Duties," Australian Journal of Philosophy (2012): 1-18.

40. On such "organizational complicity," see Chiara Lepora and Robert E. Goodin, On Complicity and Compromise (Oxford: Oxford University Press, 2013), chap. 7. See also Anders Strand, "Group Agency, Responsibility, and Control." 
For example, could a soldier's murder of an enemy at gunpoint double up as an act of complicity in a wider state aggression, and could his or her liability to attack be impacted as a result?

Such further paths of inquiry contingent on the possibility of state corporate agency are tantalizing, and hold the promise of a more fruitful integration of a salient corporate dimension in the morality of war. Of course, insofar as individualized considerations can best account for the puzzles raised here, or if the ideas of corporate agency and corporate responsibility ultimately turn out to be mistaken, then the inquiry will inevitably be of limited value. Since the jury is still out, though, I hope to have helped provide at least some focus for further investigations. 